\title{
Fish Endoparasites from Streams near Paddy Fields in Serian and Padawan, Western Sarawak
}

\author{
FELLICIA INCHING UCHANG, YANG LEE, FREDDY KUOK SAN YEO \& YEE LING CHONG* \\ Faculty of Resource Science and Technology, Universiti Malaysia Sarawak, 94300 Kota Samarahan, Sarawak, \\ Malaysia \\ *corresponding author: ylchong@unimas.my
}

\begin{abstract}
The fish health status and parasitic infection in paddy fields are understudied in Borneo. This study was done to compare the prevalence and abundance of parasites on freshwater fishes in the upstream and downstream rivers of paddy fields. Parasite study on freshwater fishes was done by collecting live fish samples using ten minnow traps with baits at each site in Serian and Padawan, Sarawak, from October 2017 until March 2018. A total of 120 freshwater fishes were examined during this study period. Cold anaesthesia was applied on live samples prior to ectoparasite and endoparasite microscopic screening, which involved scraping of outer body mucous and removal of fish intestines, respectively. No ectoparasites were recovered from the fish samples. A total of 19 (15.83\%) fishes from Cyprinids were infected with endoparasites. From these, 58 individuals of endoparasites were recovered. Two groups of parasites, namely Nematoda (Cucullanus sp.) and Trematoda (unidentified), were recovered from the fish intestines. From this study, there was a significant difference between the upstream fishes and downstream fishes in their endoparasite infection at both Triboh Village $(p=0.035)$ and Annah Rais Village $\left(\mathrm{p}=1.445 \times 10^{-6}\right)$ using two samples t-test. The endoparasite abundance in fish was higher in the streams where there was less human disturbance. This study may serve as a baseline study on the parasitic infections of freshwater fishes in streams near paddy fields or other agricultural area in Sarawak.
\end{abstract}

Keywords: Borneo, freshwater fish, parasite infection, rice fields

Copyright: This is an open access article distributed under the terms of the CC-BY-NC-SA (Creative Commons Attribution-NonCommercialShareAlike 4.0 International License) which permits unrestricted use, distribution, and reproduction in any medium, for non-commercial purposes, provided the original work of the author(s) is properly cited.

\section{INTRODUCTION}

Freshwater fishes can be infected with parasites because they consumed small crustaceans that might have previously fed on parasite eggs or larvae (Hilderbrand, Price \& Olson, 2003). In addition, they can transmit the parasites by becoming food for many other vertebrates (Barber \& Wright, 2006). The variations in the mechanism of parasitic infections towards the fishes could be attributed to abiotic and biotic conditions of the environment. As described by Ejere et al. (2014), unfavourable environmental conditions, such as adverse temperature, may offset fish physiology and thus leads to parasitic infection.

Some of the common parasites that are known to infect freshwater fishes include protozoans, trematodes, nematodes, cestodes, acanthocephalans, copepods and hirudineans (Iyaji \& Eyo, 2008). Parasites can cause mechanical damages such as discolouration to the gills of fish. In more chronic cases, infected fish will wear down, turn pale, develop white spots and increase in mucous secretion (Toksen, 2007). Apart from that, parasites can cause physiological damage such as cell proliferation, which was found similar to human diseases and may act as a causative agent for carcinogenesis in fish species (Iwanowicz, Black, Blazer, Zappia \& Bryant, 2016). Damages on fish reproductive ability by parasites were also reported. Examples include decreased female fecundity by reduction in embryo production (Deaton, 2009) and male fishes also avoid mating with parasitized females (Buchholz, 2004; Richards, van-Oosterhout \& Cable, 2010).

There was a massive expansion in the agriculture industry in Malaysia and small to large-scale agriculture activities were observed in many rural areas. This industry may have environmental effects towards the community that lives in these areas. Paddy plantation is one of the examples of agriculture industry that depletes the environment (de Miranda, Fonseca, Lima, de Moraes \& Rodrigues, 2015). As such the unionized ammonia concentration in the water can cause health depletion of fish and other organisms due to an increase in water $\mathrm{pH}$ of nearby river or stream, particularly so after applying nitrogen-rich fertilizer (Halwart \& Gupta, 2004). Unhealthy fish may lead to increase susceptibility to parasitic infection. Besides that, the villagers living around the area also depend on the fishes from the river for food source. 
There is still lacking published literature on parasitic infections of freshwater fishes in Borneo. It is necessary to understand the health status and parasite susceptibility of local freshwater fishes, which could be useful in understanding the conservation status of freshwater fishes in this region. The objective of this preliminary study was to identify the composition and parasitic infection of fishes on both upstream and downstream rivers near the paddy fields.

\section{MATERIALS \& METHODS}

\section{Study Sites and Fish Sampling}

Field samplings were carried out from September 2017 until early March 2018 where the fishes were collected from the freshwater streams or rivers near the paddy fields at Triboh Village (Serian) and Annah Rais Village (Padawan). Minnow traps with fish pellets as baits were used for fish samplings. A total of five small minnow traps and five large minnow traps were set up at each station. The minnow traps were set up at two different stations at each sampling site, which were the forested upstream river and downstream river near the paddy fields. The traps were checked twice a day at 0900 hours and 1400 hours. A total of 30 fishes were caught at both upstream and downstream stations at each site, which makes up 120 fishes altogether. Fish identification was done based on several important external morphologies such as standard length (SL), total length (TL), weight (kg) and by looking at the fin shape and snout shape. Fish identification was done using reference books by Atack (2006) and Inger and Chin (2002).

\section{Parasite Determination}

After fish samplings, the fishes were kept inside an aquarium or a container to keep the fish alive temporary. Fishes were killed humanely by euthanization, which was done by placing the live fish in a cooler filled with iced water. The outer body mucous was collected by scraping in a skull-tail direction. The collected mucous were placed on clean glass slides, mixed with saline solution, and examined under a compound microscope with $10 \mathrm{X}$ and $40 \mathrm{X}$ magnifications to detect ectoparasites (Biu, Diyaware, Yakaka \& Joseph, 2014). The whole-body cavity of fish was dissected to remove the intestine. The intestine was then placed inside a Petri dish containing distilled water and was cut open longitudinally. The Petri dish containing fish intestine was then incubated in an incubator at $40^{\circ}$ $\mathrm{C}$ and observed under a stereomicroscope every 10 minutes for the presence of endoparasites. Parasites were identified up to species level, if possible, by comparing their morphological structures with published references by Yamaguti (1963), Dailey (1996) and Roberts, Schmidt and Janovy (2009).

Scanning electron microscope (JSM-6390LA; Jeol Ltd., Tokyo, Japan) was also used to make a three-dimensional image of the surface of the parasite specimen. Before proceeding to scanning electron microscope, the samples were fixed in $2 \%$ glutaraldehyde and then dehydrated using graded ethanol series $(60 \%, 70 \%$ and $100 \%)$ for approximately 30 minutes to one hour. The samples were then subjected to Critical Point Drying (CPD) for approximately 8 hours. After the drying process, the samples were placed on aluminium plates and coated with gold before observed under the scanning electron microscope.

\section{Data Analysis}

The statistical analysis was done by using Paleontological Statistics (PAST) software to calculate the parasite's mean intensity, prevalence and parasite's abundance. Statistical t-test was used to compare data of upstream and downstream rivers for each sampling site. Below is the formulation used to calculate prevalence, mean intensity and abundance of parasites (Bush, Lafferty, Lotz \& Shostak, 1997).

$$
\begin{aligned}
& \text { Prevalence }=\frac{\text { Number of fish infected }}{\text { Number of fish examined }} \times 100 \\
& \text { Mean intensity }=\frac{\text { Number of the parasites collected }}{\text { Number of infected host }} \\
& \text { Abundance }=\frac{\text { Number of parasites collected }}{\text { Number of the host examined }}
\end{aligned}
$$




\section{RESULTS}

In this study, freshwater fishes were collected in the upstream and downstream rivers near the paddy fields in two villages located at Serian and Padawan, Sarawak. The upstream river of Triboh village is a medium-sized stream situated in between small-scale orchards owned by local villagers. Meanwhile, in the downstream river near a paddy field in Triboh Village, there were few houses at the riverbanks. The downstream river was a place where the villagers will sometime look for fishes as food source, while some villagers utilize this water source as their laundry place. A few of the villagers who live near the riverbank also kept livestock at the back of their house, and whenever they clean the shelters of their animals, the dirty water will flow into the downstream river. Annah Rais Hotspring, which is a tourism spot, served as the upstream river for the second sampling site. The river water was clear, and cyprinids were seen clearly in the water. During the time of sampling, the farmers were harvesting paddy and thus, assumed to no longer spraying pesticides. A total of 120 fishes were sampled, which represented four families (i.e. Cichlidae, Cyprinidae, Helostomatidae and Mastacembelidae) (Table 1). From this, 30 fish samples were caught from each upstream and downstream station at both villages. Barbodes genus was the most abundant fishes found in both upstream and downstream rivers at Triboh Village and Annah Rais Village. Only family Cyprinidae inhabited at upstream regions at both Triboh Village and Annah Rais Village. In the downstream region of Triboh Village, more fish species were found. These include fishes from family Cichlidae, Cyprinidae, Helostomatidae and Mastacembelidae.

Table 1. Freshwater fishes in the upstream and downstream rivers near the paddy fields at Triboh Village and Annah Rais Village, Sarawak.

\begin{tabular}{|c|c|c|c|}
\hline Site & Family & Species & Individual(s) \\
\hline \multicolumn{4}{|c|}{ Upstream } \\
\hline \multirow[t]{6}{*}{ Triboh } & Cyprinidae & Barbodes binotatus & 3 \\
\hline & & Barbodes everetti & 3 \\
\hline & & Barbodes sealei & 15 \\
\hline & & Puntius orphoides & 1 \\
\hline & & Rasbora caudimaculata & 3 \\
\hline & & Rasbora sumatrana & 5 \\
\hline \multirow[t]{3}{*}{ Annah Rais } & Cyprinidae & Barbodes binotatus & 7 \\
\hline & & Barbodes sealei & 20 \\
\hline & & Rasbora sumatrana & 3 \\
\hline \multicolumn{4}{|c|}{ Downstream } \\
\hline \multirow[t]{5}{*}{ Triboh } & Cichlidae & Oreochromis niloticus & 4 \\
\hline & Cyprinidae & Barbodes sealei & 20 \\
\hline & & Barbodes binotatus & 1 \\
\hline & Helostomatidae & Helostoma temminckii & 4 \\
\hline & Mastacembelidae & Macrognathus maculatus & 1 \\
\hline \multirow[t]{5}{*}{ Annah Rais } & Cyprinidae & Barbodes binotatus & 1 \\
\hline & & Barbodes everetti & 3 \\
\hline & & Barbodes sealei & 13 \\
\hline & & Rasbora sumatrana & 13 \\
\hline & & & 120 \\
\hline
\end{tabular}

\section{Nematodes in Rasbora sumatrana and Barbodes sealei}

The fishes were first screened for the presence of ectoparasite and through the screening process; none of the fishes were infested with ectoparasite. A total of 58 individuals consisting of two taxonomic groups of enparasites were recovered from the intestines of the examined Cyprinids in this study. Figure 1 and Figure 2 represent the images of endoparasites (nematodes and trematodes) retrieved from Cyprinids fishes. Identification of these endoparasites up to species level was not possible due to the lack of intact images on the morphological structures. Based on Dailey (1996), the most likely endoparasite group is nematode (Figure 1) and it resembled Cucullanus sp. due to the club-shaped swelling on the anterior part (Dailey, 1996). 

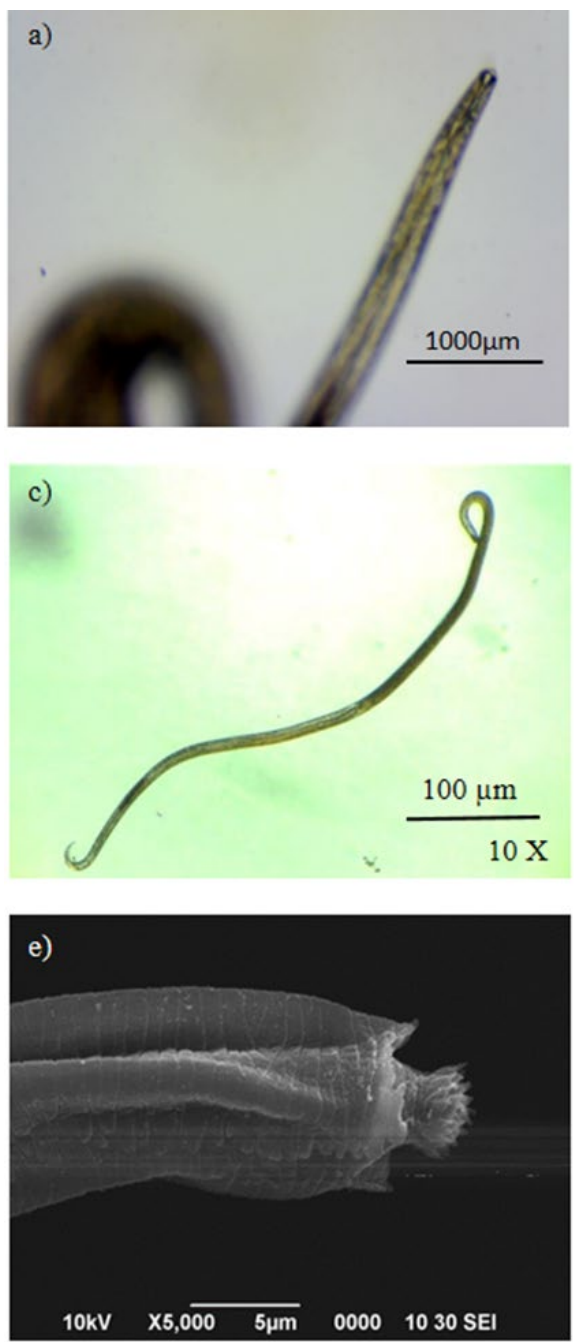
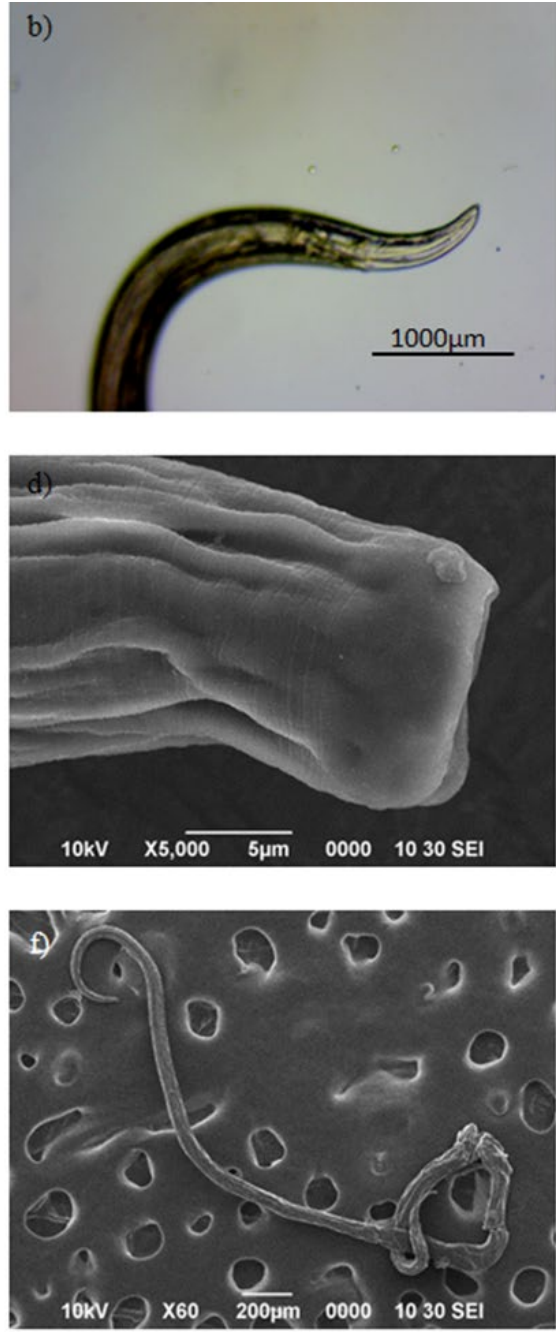

Figure 1. Cucullanus sp. recovered from the intestine of Rasbora sumatrana and viewed under both compound and scanning electron microscopes. a) anterior part, b) posterior part, and c) full-size view of nematode viewed under compound microscope. d) anterior part, e) posterior part, and f) full-size view of nematode viewed under scanning electron microscope.

\section{Unidentified Trematode in Rasbora Sumatrana}

Figure 2 is the images of a trematode parasite recovered from Rasbora sumatrana under compound and scanning electron microscope.
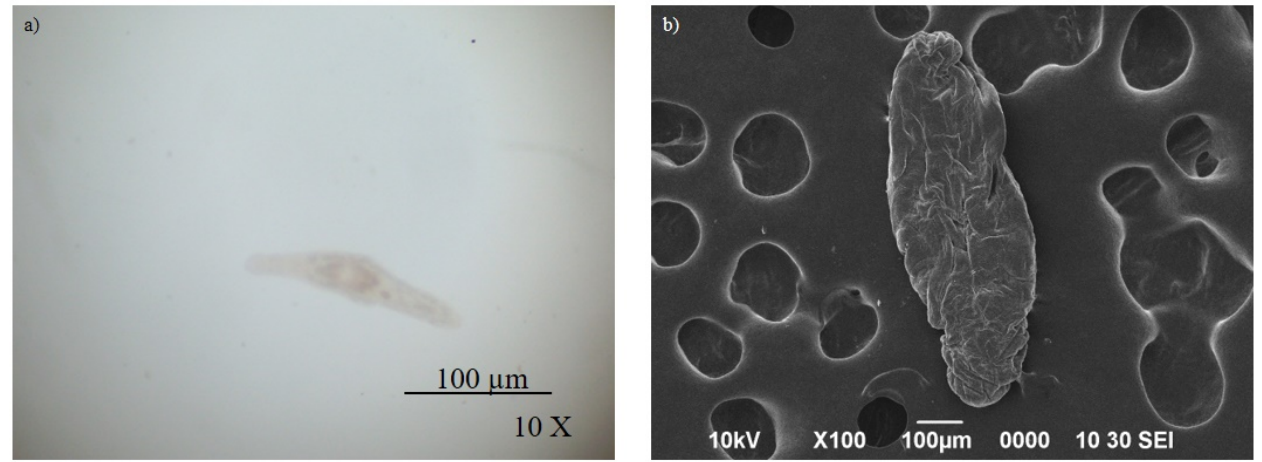

Figure 2. Unidentified trematode recovered from the intestine of Rasbora sumatrana and viewed under both compound and scanning electron microscopes. a) full-size view of trematode under stereomicroscope b) full-size view of trematode under scanning electron microscope of full-size view of unidentified trematode. 


\section{Comparison of Fish Endoparasite Infection in the Upstream and Downstream Rivers}

A total of 58 endoparasites were found in 19 infected fishes in upstream and downstream rivers in both locations (Table 2). A total of 51 individuals of enparasites were identified as nematodes due to their cylindrical and filiform morphologies (Kabata, 1985) meanwhile seven individuals were identified as trematodes by the presence of oral or ventral sucker at the mouthpart. All endoparasites were recovered in the fish intestines. Based on the observation under microscope, most measurements cannot be completed due to the poor vision of the nematode organ or special characteristics such as the reproductive organs and digestive organs. Based on Table 2, R. sumatrana shows the highest endoparasite infection prevalence with 45 endoparasites recovered from 11 infected individuals. This was followed by Barbodes sealei (12 endoparasites from seven infected individuals) and Barbodes binotatus (one endoparasite individual from an infected host). All the other species of fishes sampled at upstream and downstream of both villages were not infected with endoparasite.

Table 2. Endoparasites recovered from their host at two local villages (Triboh and Annah Rais Villages) in Western Sarawak.

\begin{tabular}{|c|c|c|c|c|c|c|}
\hline \multirow[t]{2}{*}{ Fish Species } & \multirow[t]{2}{*}{ n } & \multicolumn{2}{|c|}{$\begin{array}{c}\text { Number of fish } \\
\text { individuals with } \\
\text { endoparasites recovered }\end{array}$} & \multirow[t]{2}{*}{$\begin{array}{l}\text { Endoparasites } \\
\text { infection }(\%)\end{array}$} & \multirow{2}{*}{$\begin{array}{l}\text { Number of } \\
\text { parasites } \\
\text { recovered }\end{array}$} & \multirow[t]{2}{*}{$\begin{array}{l}\text { Endoparasite } \\
\text { Mean intensity }\end{array}$} \\
\hline & & Presence & Absence & & & \\
\hline \multicolumn{7}{|l|}{ Cichlidae } \\
\hline Oreochromis niloticus & 4 & 0 & 4 & 0.00 & 0 & 0.000 \\
\hline \multicolumn{7}{|l|}{ Cyprinidae } \\
\hline Barbodes binotatus & 12 & 1 & 11 & 8.33 & 1 & 1.000 \\
\hline Barbodes everetti & 6 & 0 & 6 & 0.00 & 0 & 0.000 \\
\hline Barbodes sealei & 68 & 7 & 61 & 10.29 & 12 & 1.714 \\
\hline Puntius orphoides & 1 & 0 & 1 & 0.00 & 0 & 0.000 \\
\hline Rasbora caudimaculata & 3 & 0 & 3 & 0.00 & 0 & 0.000 \\
\hline Rasbora sumatrana & 21 & 11 & 10 & 57.14 & 45 & 4.091 \\
\hline \multicolumn{7}{|l|}{ Helostomatidae } \\
\hline Helostoma temminckii & 4 & 0 & 4 & 0.00 & 0 & 0.000 \\
\hline \multicolumn{7}{|l|}{ Mastacembelidae } \\
\hline Macrognathus maculatus & 1 & 0 & 1 & 0.00 & 0 & 0.000 \\
\hline TOTAL & 120 & 19 & 101 & & 58 & \\
\hline
\end{tabular}

The endoparasite prevalence of fishes was high at the upstream river (30\%) near a paddy field at Triboh Village and the downstream river (23\%) of a paddy field at Annah Rais Village (Table 3). Statistical analysis using two samples t-test showed that the parasitic infection between the upstream and downstream rivers near the paddy fields was significantly different for both Triboh Village $(\mathrm{p}=0.035)$ and Annah Rais Village $\left(\mathrm{p}=1.44 \times 10^{-6}\right)$. Meanwhile, the endoparasite mean intensity of fish in the upstream rivers was also slightly higher (5.56) compared to in the downstream river (3.71). The abundance of parasites was also recorded higher in the upstream river (1.40) as compared to the downstream river (0.53).

Table 3. The endoparasite prevalence, mean intensity and abundance of freshwater fishes in upstream and downstream rivers in two local villages in western Sarawak.

\begin{tabular}{|c|c|c|c|c|c|c|}
\hline \multirow[t]{2}{*}{ Sources } & \multicolumn{2}{|c|}{ Host individuals } & \multirow{2}{*}{$\begin{array}{c}\text { Parasite } \\
\text { individuals } \\
\text { recovered }\end{array}$} & \multirow{2}{*}{$\begin{array}{c}\text { Prevalence } \\
(\%)\end{array}$} & \multirow{2}{*}{$\begin{array}{c}\text { Mean } \\
\text { intensity }\end{array}$} & \multirow{2}{*}{$\begin{array}{c}\text { Parasite } \\
\text { abundance }\end{array}$} \\
\hline & Infected & Examined & & & & \\
\hline \multicolumn{7}{|c|}{ Upstream } \\
\hline Triboh & 9 & 30 & 41 & 30.00 & 4.556 & 1.367 \\
\hline Annah Rais & 1 & 30 & 1 & 3.33 & 1.000 & 0.033 \\
\hline Overall & 10 & 60 & 42 & 33.33 & 5.556 & 1.400 \\
\hline \multicolumn{7}{|c|}{ Downstream } \\
\hline Triboh & 2 & 30 & 4 & 6.67 & 2.000 & 0.133 \\
\hline Annah Rais & 7 & 30 & 12 & 23.33 & 1.714 & 0.400 \\
\hline Overall & 9 & 60 & 16 & 30.00 & 3.714 & 0.533 \\
\hline
\end{tabular}

\section{DISCUSSION}

This study shows that the upstream river in Triboh village harboured more fish species $(\mathrm{n}=6)$ compared to the downstream river $(\mathrm{n}=5)$. Two of the species found in downstream (Oreochromis niloticus and Helostoma temminckii) were fishes that escaped from the nearby aquaculture at the riverbank but entered the minnow traps that were set up in the region. Hence, these fishes were not originally inhabitant in the river. The downstream river 
was not fast flowing and Rasbora species were not found in this region. On the other hand, Barbodes individuals can live in both slow and fast flowing waters (Martin-Smith, 1998), hence, making them abundant in both upstream and downstream rivers.

In the upstream of Annah Rais Village, there were only three fish species caught using minnow traps compared to four species at the downstream. Tourists were seen at the upstream river, which made it quite difficult for sampling. A lot of fish species were observed swimming around the traps, but not all entered the minnow traps. Another possible reason could be due to the baits used were not effective enough to lure all kinds of fishes. According to Brasher (2003), the presence of human disturbance has resulted in lower water quality and degraded physical habitats for many native stream species. The downstream river at Anna Rais Village has less human disturbance possibly due to the difficulty in accessing the area. Thus, it was a little easier to sample for fish. The farmers were also no longer seen spraying pesticides since it was already harvesting season for paddy.

The fish species that showed the highest endoparasite infection was $R$. sumatrana. This may be due to the diets of Rasbora that were primarily exogenous insects from mid-water position, although some stomach contained seeds and leaves (Bishop, 1973). In addition, invertebrates are significant to become the first intermediate hosts of parasites larvae. Most of the fish samples were B. sealei, which was found to bear little parasites from this study, or in other words, a species suspected with a strong immune system or more resistant to endoparasite infection.

In this study, the percentage of infected fish individuals was higher in the upstream rivers in Triboh Village compared to downstream rivers situated near the paddy fields. According to Pilosof, Dick, Korine, Patterson and Krasnov (2012), parasite abundance can increase where the local conditions of the environment promote the parasite development but will decrease where the environmental contaminants are harmful to the parasite. For instance, upstream fishes living in the ideal environment with forest area may provide the opportunity for the parasites to develop in the body of their host. While in the downstream river near a paddy field in Triboh village, the usage of pesticides such as herbicides in paddy fields to wilt other plants that grow on the land might cause these pollutants discharge to flow through the soil and to the nearby streams. Thus, downstream fishes may be more exposed to toxic pollutants in their habitat and hence unsuitable for the parasites to live in. Environmental effects or other anthropological activities may have both direct and indirect effects towards the abundance of parasites. Chapman, Marcogliese, Suski and Cooke (2015) mentioned that environmental conditions and pollutants have effects on the differences in abundance and community structure of parasites in fish. These different variables may become the drivers of the parasite abundance, prevalence and mean intensity in this study. According to Lafferty and Kuris (1999), although parasites may increase in association with other stressors, their population may also decrease due to the complexity of their life cycles, which makes them susceptible to other wider range of disturbances. Lafferty (1997) stated that toxic chemicals have a consistent negative effect on helminths, such as trace metals killing free-living parasites while reducing the infection rate of snails in polluted water (Siddall \& Clers, 1994).

This study observed contradicting result at Annah Rais village in which the prevalence of parasites in freshwater fish was high in the downstream river. This might be explained by the presence of a resort at the upstream river, which was constantly occupied with human. Here, human disturbances may play a role in suppressing the aquatic invertebrates, which are the major food sources for the fish and might greatly affect the ecosystem services (Olson, Stewart \& Thompson, 2016). This suggested that human interference may directly or indirectly influence the survival of the parasites in freshwater fish as well. Meanwhile, the freshwater fishes at downstream river near a paddy field in Annah Rais Village had higher endoparasite prevalence. The time of sampling may play a crucial role in the endoparasite infection of the fishes since sampling at this site was done during harvesting season, hence there were not much pesticide effluents in the river system during this period.

The endoparasites recovered from the fishes were Cucullanus sp. and unidentified trematode. Nematodes are endoparasites that are usually found living in the intestine. Shaharom (2012) stated that the important morphologies for identifying nematodes are their anterior and posterior parts. The parasite samples were delicate and likely to tear upon repositioning and its vulnerability to break after Critical Point Drying (CPD) process, thus have made it difficult to identify the species of parasites. Previous study on paddy field fishes in Malaysia showed that the common nematodes obtained were Cucullanus sp., Spinictus inermis, and Capillaria sp. (Rahman \& Bakri, 2008). 


\section{CONCLUSION}

A total of 120 individuals of freshwater fish were caught in this study, ranging from Family Cichlidae (Oreochromis niloticus), Cyprinidae (Barbodes binotatus, B. everetti, B. sealei, Puntius orphoides, Rasbora caudimaculata and R. sumatrana), Helostomatidae (Helostoma temminckii) and Mastacembelidae (Macrognathus maculatus). From these, 58 individuals of endoparasites were recovered from 19 individuals of host fish from Family Cyprinidae. Two parasite groups (Nematoda and Trematoda) were collected from the intestine of the fish samples. From this study, the parasite abundance was higher in the streams where there was less human disturbance, such as the upstream rivers with forest area in Triboh Village and downstream rivers near a paddy field in Annah Rais Village.

To note, the data presented here only serves as a preliminary result since it was generated from small sample size within a short sampling period and using only a single type of fish trap. It is recommended to have a longer sampling period so that more sites can be covered with different fish traps to compare more freshwater fish samples and to understand better the influence of paddy plantation towards the river community and parasite loads. To provide a better insight into the mechanisms of parasitic infestation in paddy fishes, fish samples should be obtained throughout the planting and harvesting seasons. The data obtained in this study may serve as a baseline study on parasitic infections of freshwater fish and how the environment plays a role in their community structure in this region.

\section{ACKNOWLEDGEMENTS}

The authors thank the Sarawak Forest Department for granting the research permit with Permit No. NPW 907.4.4.(Jld.15)-15 and Park Permit No. WL8/2018. This research was supported by fund from Tun Zaidi Chair Grant (F07/TZC/1592/2017) and approved by Universiti Malaysia Sarawak (UNIMAS) Animal Ethics Committee. The author would like to extend their gratitude to Shafri Bin Semawi, Isa bin Sait, Tan Yeong Shiun, Lim Jia Zhen, and Nur Qamareena binti Karim for their field assistance and the Faculty of Resource Science and Technology, UNIMAS for the logistic support and laboratory facilities.

\section{REFERENCES}

Atack, K. (2006). A Field Guide to the Fishes of Kuching Rivers, Sarawak, Malaysian Borneo. Sarawak, Malaysia: Natural History Publications.

Barber, I., \& Wright, H. A. (2006). Effects of Parasites on Fish Behaviour: Interactions with Host Physiology. In K. A. Sloman, R. W. Wilson \& S. Balshine (Eds.), Behaviour and Physiology of Fish vol 24 (pp. 110-133). USA: Elsevier Academic Press.

Bishop, J. E. (1973). Limnology of a Small Malayan River Sungai Gombak. The Hague, Netherlands: Dr W. Junk. B.V. Publications

Biu, A. A., Diyaware, M. A., Yakaka, W., \& Joseph, E. (2014). Survey of Parasites Infesting the Nile Tilapia (Oreochromis niloticus Linnaeus, 1758) from Lake Alau, Maiduguri, Nigeria. Nigerian Journal of Fisheries and Aquaculture, 2(2), 6-12.

Brasher, A. M. D. (2003). Impacts of Human Disturbances on Biotic Communities in Hawaiian Streams. BioScience, 53(11), 1052-1060.

Buchholz, R. (2004). Effects of parasitic infection on mate sampling by female wild turkeys (Meleagris gallopavo): should infected females be more or less choosy? Behavioural Ecology, 15(4), 687-694.

Bush, A. O., Lafferty, K. D., Lotz, J. M., \& Shostak, A. W. (1997). Parasitology meets ecology on its own terms Margolis et al., revisited. The Journal of Parasitology, 83, 575-583.

Chapman, J. M., Marcogliese, D. J., Suski, C. D., \& Cooke, S. J. (2015). Variation in parasite communities and health indices of juvenile Lepomis gibbosus across a gradient of watershed land-use and habitat quality. Ecological Indicators, 57, 564-572.

Dailey, M. D. (1996). Meyer, Olsen \& Schmidt's Essentials of Parasitology. W.C. Brown Publishers.

Deaton, R. (2011). Parasitic nematodes decrease fecundity in the western mosquitofish, Gambusia affinis. The Southwestern Naturalist, 56(2), 262-265.

De Miranda, M. S., Fonseca, M. L., Lima, A., de Moraes, T. F., \& Rodrigues, F. A. (2015). Environmental impacts of rice cultivation. American Journal of Plant Sciences, 6, 2009-2018.

Ejere, V. C., Aguzie, O. I., Ivoke, N., Ekeh, F. N., Ezenwaji, N. E., Onoja, U. S., \& Eyo, J. E. (2014). Parasitofauna of five freshwater fishes in a Nigerian freshwater ecosystem. Croatian Journal of Fisheries, 72(1), 17-24.

Halwart, M., \& Gupta, M. V. (2004). Culture of fish in rice fields. Rome: FAO.

Hilderbrand, K. S., Price, R. J., \& Olson, R. E. (2003): Parasites in marine fishes: questions and answers for seafood retailers. ORESU-G-03-015. 
Inger, R. F., \& Chin, P. K. (2002). The fresh-water fishes of North Borneo. Kota Kinabalu, Sabah, Malaysia: Natural History Publications (Borneo) Sdn. Bhd.

Iwanowicz, D., Black, M. C., Blazer, V. S., Zappia, H., \& Bryant, W. (2016). Effects of urban land-usage on largescale stonerollers in the Mobile River Basin, Birmingham, AL. Ecotoxicology, 25, 608-621.

Iyaji, F. O., \& Eyo, J. E. (2008). Parasites and their freshwater fish host. Bio-Research, 6(1), 328-338.

Kabata, Z. (1985). Parasites and diseases of fish cultured in the tropics. London, UK: Taylor and Francis Ltd.

Lafferty, K. D., \& Kuris, A. M. (1999). How environmental stress affects the impacts of parasites. Limnology and Oceanography, 44(3, part 2), 925-931.

Lafferty, K. D. (1997). Environmental parasitology: What can parasites tell us about human impacts on the environment? Parasitology Today, 13, 251-55.

Martin-Smith, K. M. (1998). Diversity of freshwater fishes from eastern Sabah: annotated checklist for Danum valley and a consideration of inter-and intra- catchment variability. The Raffles Bulletin of Zoology, 46(2), 573-604.

Olson, A. R., Stewart, T. W., \& Thompson, J. R. (2016). Direct and indirect effects of human population density and land use on physical features and invertebrates of Iowa (U.S.A.) streams. Urban Ecosystem, 19(1), 159180.

Pilosof, S., Dick, C. W., Korine, C., Patterson, B. D., \& Krasnov, B. R. (2012). Effects of anthropogenic disturbance and climate on patterns of bat fly parasitism. PLOS ONE, 7(7), e41487.

Rahman, W. A., \& Bakri, M. (2008). On the endoparasitic fauna of some paddy-field fishes from Kedah, Peninsular Malaysia. Journal of Bioscience, 19(2), 107-112.

Richards, E. L., van-Oosterhout, C., \& Cable, J. (2010). Sex-specific differences in shoaling affect parasite transmission in guppies. PLoS ONE, 5(10), e13285.

Roberts, L. S., Schmidt, G. D., \& Janovy, J. (2009). Foundations of Parasitology. In G. D. Schmidt, L. S. Roberts, (Eds.). Boston: McGraw-Hill Higher Education.

Shaharom, F. (2012). Fish parasites of Lake Kenyir, Peninsular Malaysia. Kuala Terengganu. Terengganu: UMT Publisher, Universiti Malaysia Terengganu.

Siddall, R., \& Clers, S. D. (1994). Effect of sewage sludge on the miracidium and cercaria of Zoogonoides viviparus (Trematoda: Digenea). Helminthologia, 31, 143-53.

Toksen, E. (2007). Lernanthropus kroyeri van Benden, 1841 (Crustacea: Copepoda) infections of cultured sea bass (Dicentrarchus labrax L.). Bulletin of the European Union of Fish Pathologists, 27, 49-53.

Yamaguti, S. (1963). Parasitic Copepoda and Branchuira of fishes. NY, New York: Interscience Publishers. 